\title{
Design instrucional e as conjunturas sexistas presentes nas produções do design e da área comunicacional
}

\author{
Instructional design and the continuous sexist circumstance at design \\ and communicational productions area
}

\author{
Victor Kraide Corte Real, Ana Júlia Broglio, Lívia Barbosa Gurgel, Mariana Magalhães \\ Camacho Echeverre, Nycolas Pedro Martins Lima, Vitória Xavier Bailoni
}

design instrucional, sexismo, propaganda, comunicação, mídia

O presente trabalho aborda a permanência de conceitos e construções sexistas dentro do processo de produção da comunicação, destacando o Design e áreas correlatas como grandes propiciadoras de peças gráficas, produtos e propagandas com este tipo de discriminação. Analisando brevemente a relação entre comunicação, estereótipo, propaganda e representação feminina, entende-se que ao comunicador recai a responsabilidade, a ética e a possibilidade da mudança, ao passo que ele detém as ferramentas conceituais e práticas para iniciar um novo cenário das mídias comunicacionais brasileiras. Ao final, são apresentadas duas propostas de ação projetual baseadas no método de design instrucional de Filatro e Piconez (2004). As propostas em questão têm por intuito informatizar e promover conhecimento a todos os profissionais.

instructional design, sexism, advertisement, communication, media

This work targets the ongoing sexist concepts and constructions on the communication production process, highlighting design and related areas as great enablers of graphic pieces, products, and advertisements with this kind of discrimination. A brief analysis on the relation between communication, stereotype and female representation, understanding that falls back upon the communicator the responsibility, the ethic, and the possibility of change, while he holds the conceptual and practical tooling to start a new scenario for the communicational media in Brazil. In conclusion, two action projects ideas are presented based on instructional design methods of Filatro and Piconez (2004) to inform and promote knowledge to all professionals.

\section{Introdução}

De acordo com Löbach (2011, p. 16), Design é definido como uma ideia ou plano a ser desenvolvido, projetado ou posto em prática para solucionar um determinado problema ou questão; ao final deste processo, é necessário que se transmita a mensagem da solução para as partes interessadas - clientes, usuários ou consumidores. Desse modo, entende-se que o método de Design propõe a resolução de problemas a partir de um determinado método para sua concretização. Este processo de solução alinha-se ao processo criativo, à

Anais do $10^{\circ} \mathrm{CIDI}$ e $10^{\circ} \mathrm{CONGIC}$

Kelli C.A.S. Smythe, Rafael de Castro Andrade (orgs.)

Sociedade Brasileira de Design da Informação - SBDI

Curitiba | Brasil | 2021
Proceedings of the $10^{\text {th }} \mathrm{CIDI}$ and $10^{\text {th }} \mathrm{CONGIC}$

Kelli C.A.S. Smythe, Rafael de Castro Andrade (orgs.)

Sociedade Brasileira de Design da Informação - SBDI Curitiba | Brazil | 2021 
medida que o resultado objetiva ser um produto que atenda às necessidades e demandas de um dado consumidor.

Contudo, a atuação do profissional oriundo do campo do Design tem sido alvo de um debate extenso desde as origens da designação do termo designer: segundo Calegari et al. (2013), a criação da escola alemã de Artes e Design Bauhaus, no início do século XX, acompanhou o cenário tecnológico que despontava na época, o qual previa a consolidação da Revolução Industrial e suas consequências para a formação do Design como é conhecido atualmente.

Segundo Almeida e Sousa (2013, p. 71), a atuação inicial deste tipo de profissional surgiu em consonância com o aprimoramento industrial, de forma que o designer era entendido como um indivíduo o qual prestava serviços autônomos de cunho criativo. O curso de graduação "Desenho Industrial" se alocou ao currículo de bacharelados brasileiros com a pretensão de formar trabalhadores criativos e integrados ao mercado. Entretanto, atualmente, coexistem algumas vertentes de Design inerentemente multidisciplinares e conjuntas com áreas correlatas da comunicação e criatividade. Sendo assim, devido às demandas mercadológicas cada vez mais frequentes, à ascensão do consumidor $4.0 \mathrm{em}$ plena Era da Internet e à intensificação do número de times profissionais em empresas do estilo startup, é imprescindível que o designer contemporâneo atue não apenas como produtor, mas principalmente como gerente de projetos e gestor organizacional do processo criativo.

Assim, o designer se compromete com o projeto desde a sua elaboração até a distribuição final para os usuários e consumidores em forma de produto ou serviço. Neste fenômeno, entende-se que há uma questão de responsabilidade delimitada entre produtor e receptor, à medida que o objetivo principal do primeiro é produzir uma mensagem que comunique a solução para o problema do segundo. Então, a comunicação produzida não pode sofrer ruídos interpretativos ou ambiguidades por nenhum dos lados.

Conforme abordado por Löbach (2011, p. 16), sabe-se que o Design ocorrerá somente através da transmissão comunicacional da ideia projetada: entretanto, o debate sobre o conteúdo destas soluções - sejam peças gráficas, serviços, objetos industriais etc - e a questão ética presente neste desenvolvimento também necessitam de atenção, à medida que mensagens de caráter preconceituoso ou de origem manipulativa podem permear o processo criativo e contaminar o produto. Seja na realização de um projeto de branding ou de uma campanha de marketing, Rati e Beccari (2020, p. 11) sempre indicam que o principal objetivo é traduzir os anseios e as necessidades do público-alvo. Porém, é comum ocorrerem equívocos que culminam na reprodução de estereótipos sociais, e é nesse sentido em que se manifestam projetos de caráter ofensivo, sendo que alguns dos casos de ocorrência mais comuns estão diretamente relacionados ao sexismo.

Nesse contexto, segundo Filho et al. (2011), o sexismo é definido como um conjunto de atitudes e comportamentos discriminatórios ou preconceituosos baseados no gênero ou sexo de um indivíduo. Geralmente, as mulheres são as mais afetadas; entretanto é importante ressaltar que qualquer pessoa está vulnerável diante do cenário sexista o qual envolve a sociedade desde a sua formação como tal. Nesse sentido, há duas subdivisões do problema 
encontradas na literatura psicológica, entendidas como as formas principais de manifestação do sexismo: o hostil e o benévolo.

O primeiro se refere ao modo clássico e propriamente ofensivo de descrever e normatizar a mulher, entendendo-a como um ser totalmente diferente do homem, frágil, inerentemente mantenedora do lar e da família e inferior em relação ao homem. Isto legitima a postura paternalista e protetora, já que há a crença de que o sexo masculino, por dotar o poder e a força naturais, tem o dever de proteger e guiar as mulheres, permeando a dominação masculina.

O segundo, abordado por Formiga (2007), diz respeito aos aspectos sutis, menos visíveis e à primeira vista positivos, encontrados nos diferentes tratamentos dados entre homens $\mathrm{e}$ mulheres. Entretanto, são comportamentos que perpetuam a necessidade de atenção e proteção da mulher por parte de uma figura masculina, reforçando o espectro preconceituoso da situação. Em uma sociedade regida por raízes patriarcais e demarcadas pela noção da figura superior do homem, atos sexistas ocorrem o tempo todo e muitas vezes são despercebidos por serem conceitos tão arraigados na sociedade. Assim, de acordo com Ferreira (2004), o patriarcado reforça valores de socialização em que a masculinidade representa força, dominação e responsabilidade pelo sustento da família, enquanto a feminilidade representa a submissão e o cuidado da família e do lar.

Desta forma, tais representações acabam justificando um ideal de supremacia masculina, conceito que limita homens e mulheres com valores binários de gênero, que privilegiam os homens na sociedade, rebaixando mulheres a cargos inferiores. E o sexismo, sustentado pelo patriarcado, também não afeta negativamente somente as mulheres, mesmo privilegiando o gênero masculino: este ainda limita os homens e os reprimem quando não seguem os papéis tidos como verdadeiramente masculinos.

E devido à normalização dessa estrutura patriarcal consolidada há séculos, é necessário que se concretize uma ruptura imediata destes conceitos no imaginário social enquanto a área da comunicação detém um grande poder para influenciar novas ideias em larga escala. Porém, este mesmo poder é também muito utilizado para continuar a reforçar atitudes e ideais sexistas - mesmo que indiretamente - e, sendo assim, é importante analisar as peças produzidas no intuito de evitar a permanência do problema. É, portanto, objetivo deste trabalho estudar as conjunturas sexistas presentes nos meios de produção do Design e das áreas comunicativas, entendendo o profissional da comunicação como responsável pelas obras que produz e capaz de repensá-las em prol do combate contra o reforço de estereótipos na sociedade. Assim, faz-se um projeto de design instrucional, visando a educação de estudantes, designers e comunicadores frente ao conteúdo desprovido de discriminação e desinformação. 


\section{Referencial Teórico}

\section{Comunicação e Design}

Harold Lasswell, considerado um dos pais da formação da teoria da comunicação tradicional, aborda o estudo da relação estabelecida em um meio comunicacional a partir de seu modelo denominado "paradigma comunicacional lasswelliano", conforme Sousa et al. (2006, p. 5) Segundo este panorama, para atingir uma comunicação efetiva, é necessário atentar-se a quatro fatores distintos, aplicando-os de forma conjunta e de acordo com a teoria de Sousa et al. (2006) o emissor (quem?); o conteúdo (diz o quê?); o meio (por qual canal?); o receptor (para quem?); e a influência desejada desse processo (com que efeito?). Com base nestas perguntas, é possível estudar o fenômeno comunicacional por inteiro, de modo que este conteúdo permanece vivo em inúmeras teorias atuais da área.

Entretanto, vale ressaltar o papel do receptor nesta relação: de acordo com Cambrón e Jané (2006) apud Carvalho (2012, p. 39), o destinatário do conteúdo era visto como uma figura passiva, totalmente influenciada pelos domínios do produtor; afinal, o segundo desfrutava da plena consciência e poder sobre os efeitos que desejava alimentar em sua audiência. Desse modo, o modelo lasswelliano prevê que nem mesmo os fatores externos influenciam no processo, como os relacionamentos entre amigos e familiares dos receptores - o que, atualmente, se prova o contrário: os aspectos de consumo, cultura, hábitos, psicologia e comportamentos sociais são definitivos para a compreensão do fenômeno comunicativo.

Ainda, não se pode afirmar que Lasswell não se debruçava sobre o entendimento acerca do receptor; em seu modelo, o conteúdo era priorizado, mas era necessário conhecer o públicoalvo para se traçar a melhor estratégia de persuasão. Em seu livro "Propaganda Technique in the World War" (A Técnica de Propaganda na Guerra Mundial, em tradução literal), o autor discorre acerca dos motivos que levaram a população estadunidense à época da Segunda Guerra Mundial a optar favoravelmente pelo massacre ocorrido entre o país e a Alemanha. Harold debita este crédito à propaganda governamental (Figura 1), que se dedicou a um planejamento do conteúdo, dos canais de distribuição (principalmente rádio e cartazes), do receptor e da situação pré-guerra. De modo a projetar os alemães como inimigos da nação e a promover a amizade e a cooperação internas, as técnicas de propaganda auxiliaram a direcionar a opinião pública, ainda segundo Carvalho (2012).

Neste cenário, percebe-se a real influência exercida pelos produtores de conteúdo sobre aqueles que o consomem. Pensando no panorama contemporâneo do campo da comunicação, é indubitável que a consolidação da Web 3.0 modificou a situação tecnológica e moldou avanços científicos em conjunto com as consequências da Revolução Industrial, acarretando na transformação de paradigma entre consumidores e produtores. $O$ acúmulo de informações geradas e consumidas todos os dias na Internet, a emergência das redes sociais e o acesso cada vez maior dos conteúdos e dos meios de produção massivos propriamente ditos provocaram o fenômeno do chamado consumidor 3.0, distanciando-se da relação passiva antigamente imposta pelo processo comunicacional. 
Figura 1: propaganda veiculada pelo governo norte-americano em período de guerra.

Fonte: https://pt.wikipedia.org/wiki/Tio_Sam

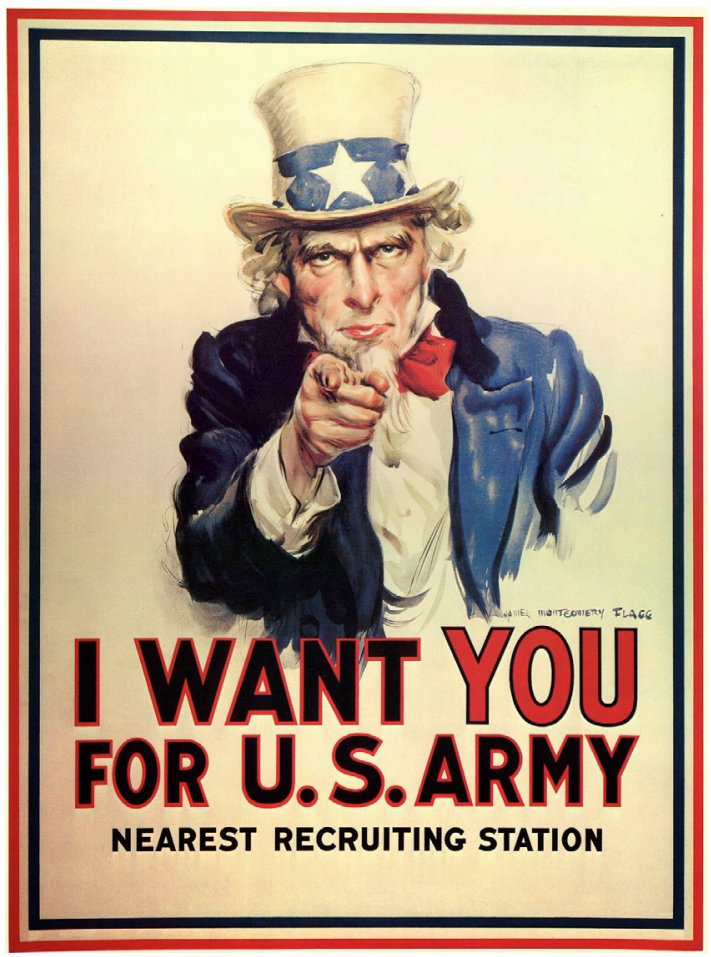

Royo (2008) contextualiza a questão abordando a participação crescente da audiência, a qual alocou espaço e contribuição nos debates e nas decisões de marketing com a migração total das mídias tradicionais - rádio, televisão, revista e jornal - para os aportes digitais. Sendo assim, internautas de todo o mundo desfrutam do acesso e à interação com marcas, produtos, serviços e bens de modo instantâneo e próximo aos produtores. A qualquer momento, alguém pode tecer uma crítica a uma companhia através de um clique no site ReclameAqui, ou ainda compartilhar para milhares de indivíduos alguma ação promovida por seu produto favorito.

Desse modo, entende-se que a responsabilidade pelo conteúdo produzido sempre recaiu nas mãos do comunicador: mesmo antes do boom tecnológico, os consumidores já eram suscetíveis à propaganda e aos produtos que consomem. Com a consolidação dos meios digitais, o mesmo público se empoderou e adquiriu espaço na discussão, representando uma enorme influência sob o modo com o qual os designers e os profissionais da área realmente realizam seu processo criativo, desde a elaboração até o desenvolvimento final.

A sua relação deixou de ser unidirecional (produtor - receptor) e adquiriu a forma multidirecional, possibilitando uma participação conjunta. É por este motivo que tais profissionais devem redobrar o cuidado e o manejo com o qual executam e corporificam suas escolhas, à medida que uma decisão mal concebida ou mal executada pode impactar $\mathrm{e}$ provocar o descontentamento e a frustração de seu próprio público; é decerto que este pode reagir ou sofrer consequências destes atos - como no caso de uma mensagem preconceituosa reforçar e fomentar padrões e posturas discriminatórias e violentas na sociedade. Portanto, as áreas relacionadas à comunicação precisam estudar a melhor maneira de uma mensagem ser 
compreendida pelo maior número de pessoas possível, de modo a compreender suas necessidades e reivindicações.

\section{Gênero e Sexo}

O termo sexo é a definição biológica que delimita os órgãos feminino e masculino, enquanto o gênero é definido socialmente, por meio do papel que um homem e uma mulher exercem na sociedade a partir da relação entre os sexos masculino e feminino. Sendo assim, de acordo com Oka e Laurenti (2018, p. 244), a partir do momento em que se é identificado o sexo de um indivíduo, culturalmente já lhe é imposto um papel de gênero, sendo por definição uma construção social. Os mesmos autores abordam tal relação social sendo o gênero uma inscrição, a marca cultural sobre a maneira como a sociedade constrói as diferenças sexuais, atribuindo papéis sociais diferentes a homens e mulheres.

Segundo Nucci (2010, p. 13), a percepção da relação do conceito de gênero antigamente era associada diretamente ao sexo biológico, entretanto, até o século XVIII acreditava-se que homens e mulheres, por mais que diferentes em termos biológicos e sociais, possuíam um sexo único: a mulher era vista como um "homem invertido", ou seja, seu sexo era na verdade inverso ao homem, já que sua genitália estaria escondida e não exposta como do órgão masculino. Logo, ela seria imperfeita e inferior, enquanto o masculino seria o sexo ativo e hierarquicamente superior.

Essa concepção de sexo único se perdeu após o final do século XVIII, criando uma teoria de que os sexos masculino e feminino seriam realmente diferentes e opostos; porém, a relação hierárquica se manteve, com a justificativa do sexo feminino ser mais frágil, dotado de um corpo problemático e instável, com sua natureza inerentemente materna e, portanto, ter como único papel uma vida confinada aos cuidados do lar. Nucci (2010, p. 14) ressalta a ideia de que a mulher também não poderia interferir na política ou em posturas administrativas, já que não possuiria a mesma estabilidade emocional do homem.

As concepções binárias de gênero se mantiveram firmes por séculos, sempre como justificativa da inferioridade feminina, reforçando a hierarquia patriarcal que se vê presente até hoje na forma do sexismo. Sua manifestação pode se desdobrar nos modelos hostil ou até mesmo benévolo, conforme abordado anteriormente. Neste cenário, Belo et al. (2005) apud Glick \& Fiske (2001b) explicitam a relação consolidada entre os dois modelos:

Os dois tipos de sexismo, hostil e benévolo, são produtos da estrutura relacional entre os sexos, sendo expressos através de ideias como as de que os homens são tipicamente constituídos de mais poder que as mulheres; que homens e mulheres são frequentemente diferenciados em termos de papel social; e que as relações entre homens e mulheres são condicionadas apenas pela reprodução sexual (Glick \& Fiske, 2001b) (BELO et al., 2005).

O tipo de sexismo mais recorrente na área comunicacional se dá ao benévolo, sobre o qual se faz um discurso da inferioridade feminina indiretamente por meio do reforço de atitudes sexistas, como a objetificação e a hipersexualização da mulher como objeto de desejo sexual para propaganda de alguma peça publicitária ou produto. A sexualização do corpo feminino 
como única função da mulher é um conceito de séculos em que seu único objetivo seria se tornar mãe e saciar os desejos sexuais do homem.

Exemplos de propagandas sexistas eram facilmente encontrados em comerciais de cerveja como no exemplo da Campanha Vai Verão de 2016 (figura 2), que causou polêmica à época. Nesta propaganda, a quantidade em milímetros do silicone da modelo é sugerida como se fosse equivalente a quantidade em milímetros da cerveja - um exemplo da objetificação da mulher como um utensílio de prazer e satisfação geralmente acrescida à figura masculina.

Figura 2: Propaganda da Cervejaria Petrópolis - Itaipava 100\%. Fonte:

https://super.abril.com.br/sociedade/os-10-comerciais-de-cerveja-mais-machistas-dos-ultimos-tempos/
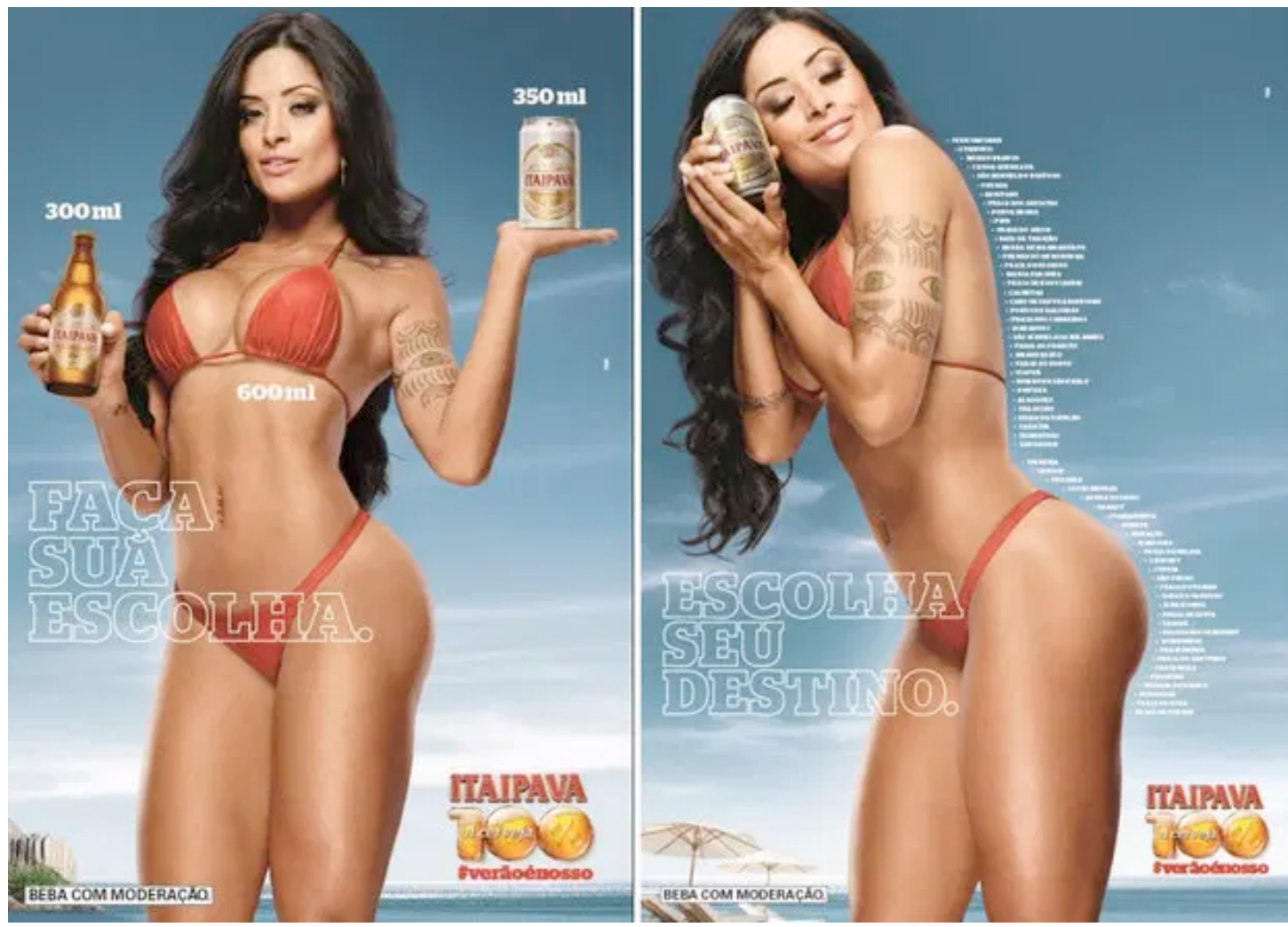

Entretanto, este tipo de estratégia sexista perdura até os dias de hoje, como é possível observar em um caso internacional do comercial da marca KFC veiculado no ano de 2020 (Figura 3). O vídeo de apenas 15 segundos exibe uma mulher ajustando o sutiã em frente a uma janela fechada de um carro; em seguida, a janela é abaixada e a cena demonstra dois meninos boquiabertos encarando os seios da figura feminina. Segundo entrevista concedida ao jornal online The Guardian (2020), a porta-voz do grupo feminista The Collective Shout, Melinda Liszewski, afirmou: "propagandas como essa reforçam a falsa ideia de que não podemos esperar mais dos meninos. É outra manifestação da máxima 'garotos serão garotos"” (LISZEWKI, 2020, nossa tradução ${ }^{1}$ ).

\footnotetext{
1 "Ads like this reinforce the false idea that we can't expect better from boys. It is another manifestation of the 'boys will be boys' trope" (LISZEWKI, 2020).
} 
Figura 3: Comercial da KFC veiculada nas redes sociais no início do ano de 2020. Fonte: https://www.theguardian.com/world/2020/jan/21/kfc-apologises-for-sexist-ad-that-shows-young-boysstaring-at-womans-breasts

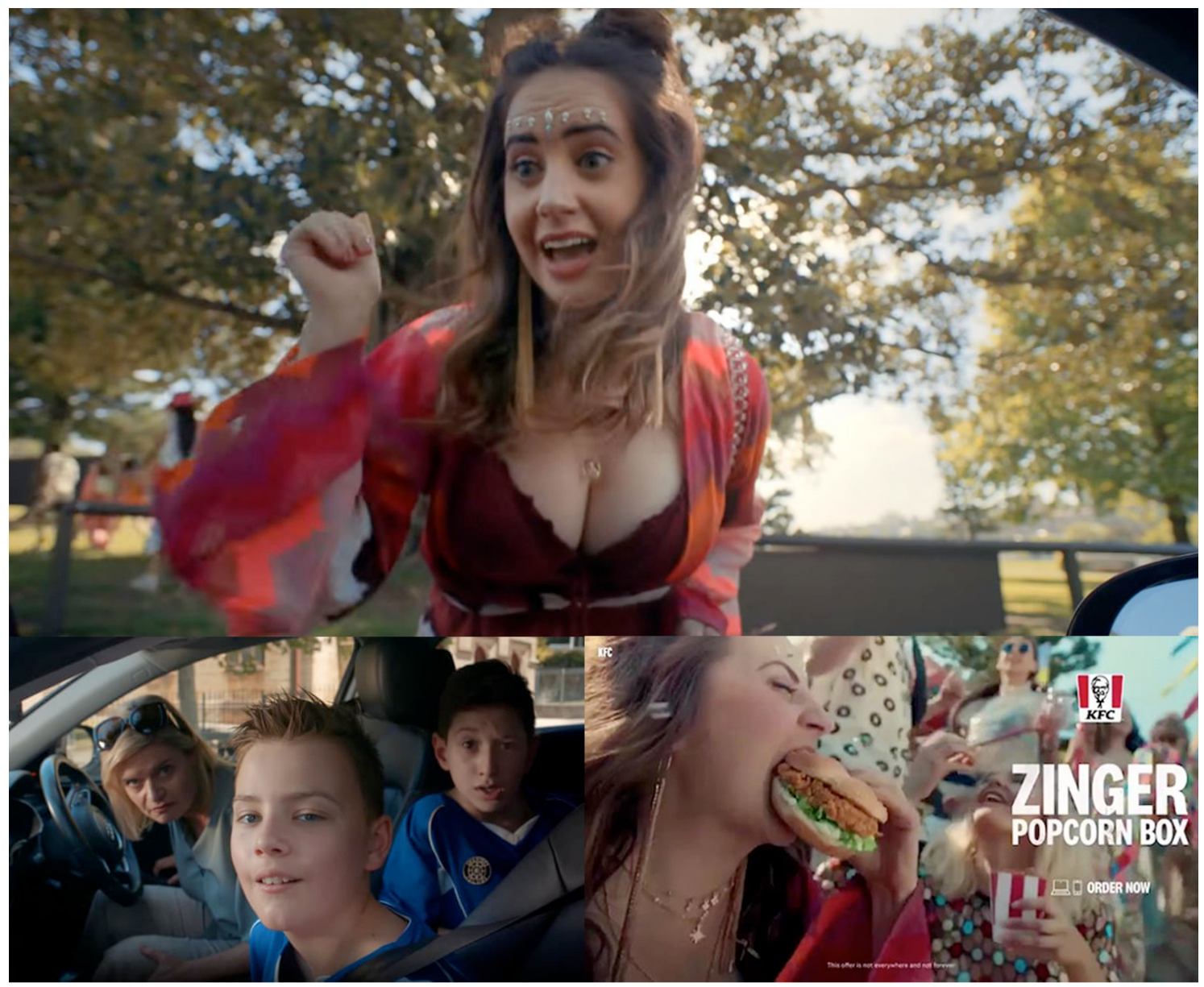

\section{Proposta de Ações Projetuais}

Com base nos dados apresentados sobre estereótipo, comunicação e representação feminina e sua relação no panorama atual da propaganda no Brasil, foram selecionadas duas ações projetuais para atuar de maneira conjunta e complementar: a formulação de um e-book ilustrado e a criação de peças de comunicação para uma conta do Instagram e Facebook. A escolha por plataformas digitais se baseia em dois motivos principais: na acessibilidade em larga escala à dispositivos mobile de usuários brasileiros e no amplo alcance de divulgação e rápido compartilhamento de informações e conteúdos diariamente entre internautas - segundo uma pesquisa de âmbito nacional promovida pelo Instituto Brasileiro de Geografia e Estatística (IBGE, 2018) e abordada por Paiva (2020), o smartphone despontou como o primeiro meio de acesso à Internet no domicílio. Além disso, mesmo com a aplicação essencialmente digital, a ideia é que haja futuramente a possibilidade da materialização do e-book por meio de sua impressão, seja através de uma impressora domiciliar ou do maquinário de gráficas.

Assim, a escolha das duas redes sociais tem como base a grande influência e o alcance que possuem devido à quantidade significativa de usuários em suas plataformas, com cerca de 
2,6 bilhões de usuários ativos mensalmente no Facebook e 1 bilhão de usuários ativos mensalmente no Instagram de acordo com a pesquisa da We Are Social de julho de 2020 (Figura 4).

Figura 4: Redes sociais com maior quantidade de usuários ativos por mês. Fonte: https://wearesocial.com/digital-2020

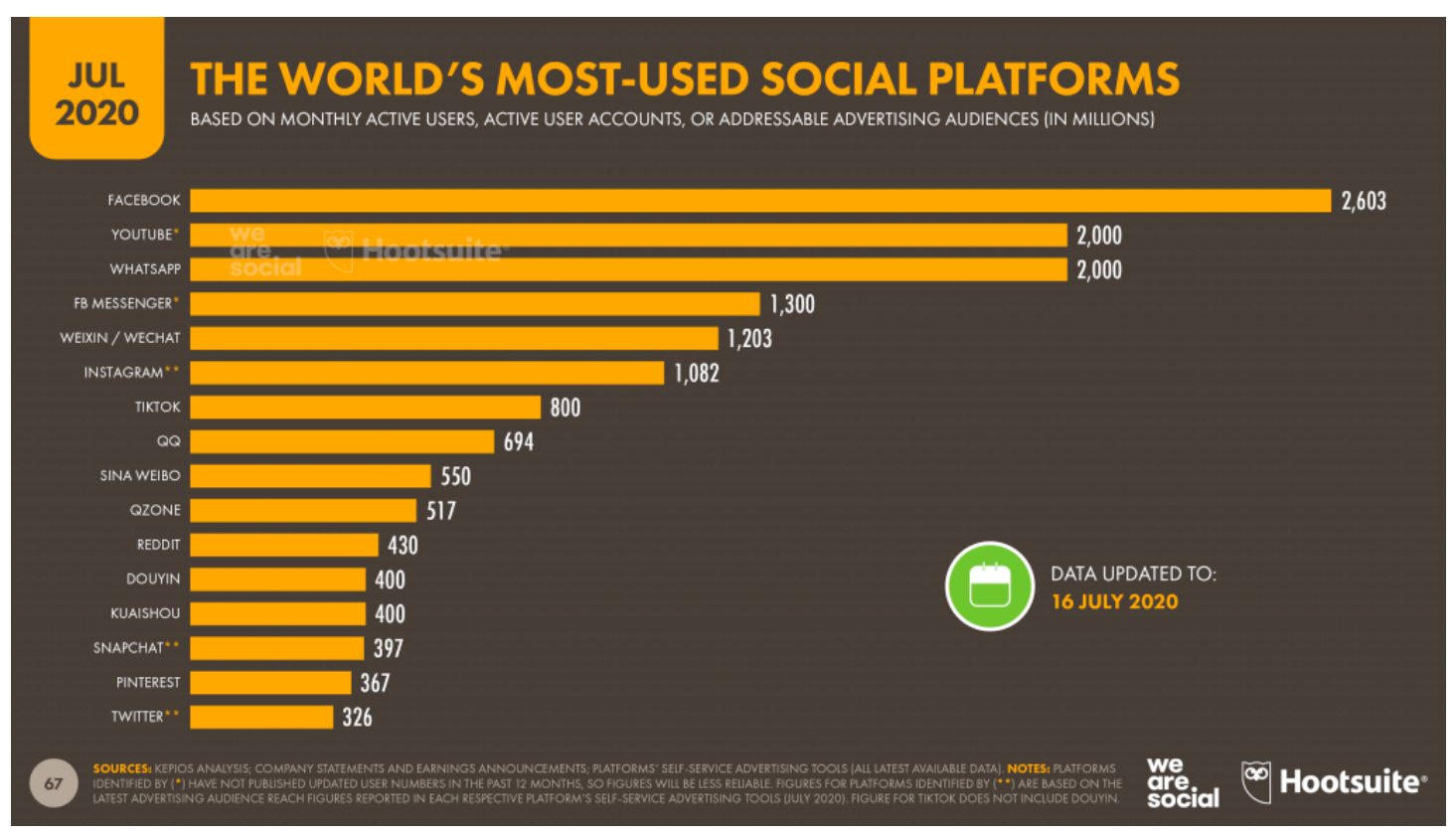

De acordo com a SocialBakers (2019), o Instagram, por mais que não integre a mesma quantidade de usuários que o Facebook, ainda o supera em questão de engajamento, já que em 2019 a sua audiência total superou o tamanho da audiência do Facebook. Nesta plataforma, a veiculação de imagens, fotos e conteúdos visuais são o maior destaque e os conteúdos mais acessados. Já a vantagem de utilizar o Facebook reside também no mecanismo com o qual usuários dentro da própria rede podem compartilhar o conteúdo em grupos de vários nichos diferentes da área da Comunicação, contribuindo para que conteúdos dos posts se espalhem de forma ampla, sem se preocupar em ter necessariamente vários seguidores na página ou patrocinadores.

Como o Instagram e o Facebook possuem formatos semelhantes de publicação, é possível produzir posts que funcionem igualmente para ambas as plataformas. Diferentemente de outras plataformas como o WhatsApp, TikTok, Reddit e Twitter, com um grande número de usuários, estas contam com um formato de visualização de conteúdo diferente das abordadas pelo projeto, exigindo que os posts que produzimos sejam adaptados para tais plataformas.

Vale ressaltar também que a informação deve alcançar um patamar acessível e procurado pelos usuários em questão, que englobam produtores de conteúdos e produtos cujo consumo será realizado por indivíduos de todas as faixas etárias, classes sociais e demandas. Sendo assim, as ações projetuais necessitam se incorporar aos meios comunicativos vigentes, integrando o leque ferramental dos profissionais e ganhando espaço no trabalho diário da produção de propagandas, peças gráficas e produtos de design. A responsabilidade inerente 
aos comunicadores pede por ações facilmente alcançáveis, flexíveis e adaptáveis para todos os contextos de uso e público-alvo.

Já a relação presente entre os posts e o livro virtual se dá a partir da utilização das redes sociais; ao visualizar as publicações promovidas por uma conta ativista e informativa, o usuário pode visitá-la e descobrir o seu conteúdo. Dados de cunho instrucional e informativo estarão contidos na conta, com imagens e recursos textuais sobre pequenas dicas, tutoriais e explanações para comunicadores em geral. Desse modo, tanto o e-book quanto os posts seguirão a formulação do método de design instrucional de Filatro e Piconez (2004), o qual se debruça em ferramentas específicas para a elaboração de conteúdo didático voltado a usuários virtuais.

Entre os dados expostos de maneira simples, direta, com linguagem informal e visualmente convidativa, é possível localizar a divulgação do e-book e acessá-lo via link da Bio: o livro conterá maiores explicações e guias sobre o panorama do sexismo presente em peças gráficas e nos meios comunicativos, com margens de respiro e dados hierarquizados acompanhados por suportes ilustrativos. Ao final do material, haverá a opção de baixá-lo ou imprimi-lo, dependendo da preferência do usuário e contribuindo para a divulgação boca a boca e virtual das ações projetuais.

O método de design instrucional de Filatro e Piconez (2004) ampara-se nos estudos recentes do planejamento educacional consolidado nos suportes digitais, entendendo o contexto e a integração entre educador e usuário como fatores principais dentro da análise. Assim, para as autoras, o design instrucional é compreendido como o planejamento do ensinoaprendizagem, incluindo atividades, estratégias, métodos e materiais instrucionais.

Entretanto, seu modelo de design instrucional contextualizado - como é definido em seu artigo -, diferentemente da literatura tradicional, aborda as fases de Análise, Design e Desenvolvimento, Implementação e Avaliação de modo contínuo e iterativo, de modo a mesclar, refazer ou sobrepor fases dependendo das condições e demandas do projeto instrucional.

Por fim, entende-se que o método se ancora nos benefícios que a Internet pode trazer à relação entre educador e aluno/usuário, interpretando que o segundo impõe autoridade e decide quais conteúdos tratar, como lidar com o compartilhamento das informações e de que modo desenrolar o seu processo de aprendizagem em consonância com a expertise do profissional comunicador. Afinal, os recursos da interatividade, o feedback constante entre os dois lados da comunicação e a construção coletiva de conhecimento online podem definir novos estilos do método de ensino-aprendizagem dentro da área do Design e áreas correlatas.

\section{Posts para Redes Sociais}

Visando um alcance amplo de público (conforme abordado anteriormente) e priorizando instrumentos próprios do design instrucional, foram produzidas duas sequências de postagens para Facebook e Instagram destinadas a compor o feed da futura conta DesignSexistaAquiNão em ambas redes - no segundo caso, as artes irão alinhar-se em formato de carrossel para feed. As próprias contas de ambas redes sociais atuarão de modo a analisar, desenvolver, 
implementar e avaliar seus conteúdos, produzindo um ciclo de design amparado no usuário e de acordo com as premissas de iteratividade e instrução próprias de Filatro e Piconez (2004).

\section{Primeiro Carrossel de Posts}

O conteúdo ampara-se em uma chamada verbal seguida de uma ilustração para um tema recorrente encontrado nas expressões populares e na mídia em geral. Com o intuito de informar o usuário sobre os perigos conceituais da popular "tomara que caia" e orientar acerca de um novo termo ("blusa sem alça"), é utilizada uma diagramação simples, com espaços de respiro entre as margens e os elementos visuais; a tipografia é Eina Sans, inerente ao mundo digital por não possuir serifa e se configurar como uma família tipográfica com número de pesos razoável para utilização. As ilustrações e as imagens servem como suporte visual e fornecem referências para o leitor mais interessado. Frases instrucionais em laranja enfatizam dicas e atitudes voltadas ao combate da discriminação. Ao final, há o direcionamento para o acesso ao e-book com mais informações e dicas sobre o tema, ativando um engajamento orgânico e formulando a possibilidade do compartilhamento de conhecimento entre os próprios usuários (Figura 5). 
Figura 5: Exemplo de mockup do primeiro carrossel de posts para Instagram e Facebook. Fonte: elaborado pelos autores.

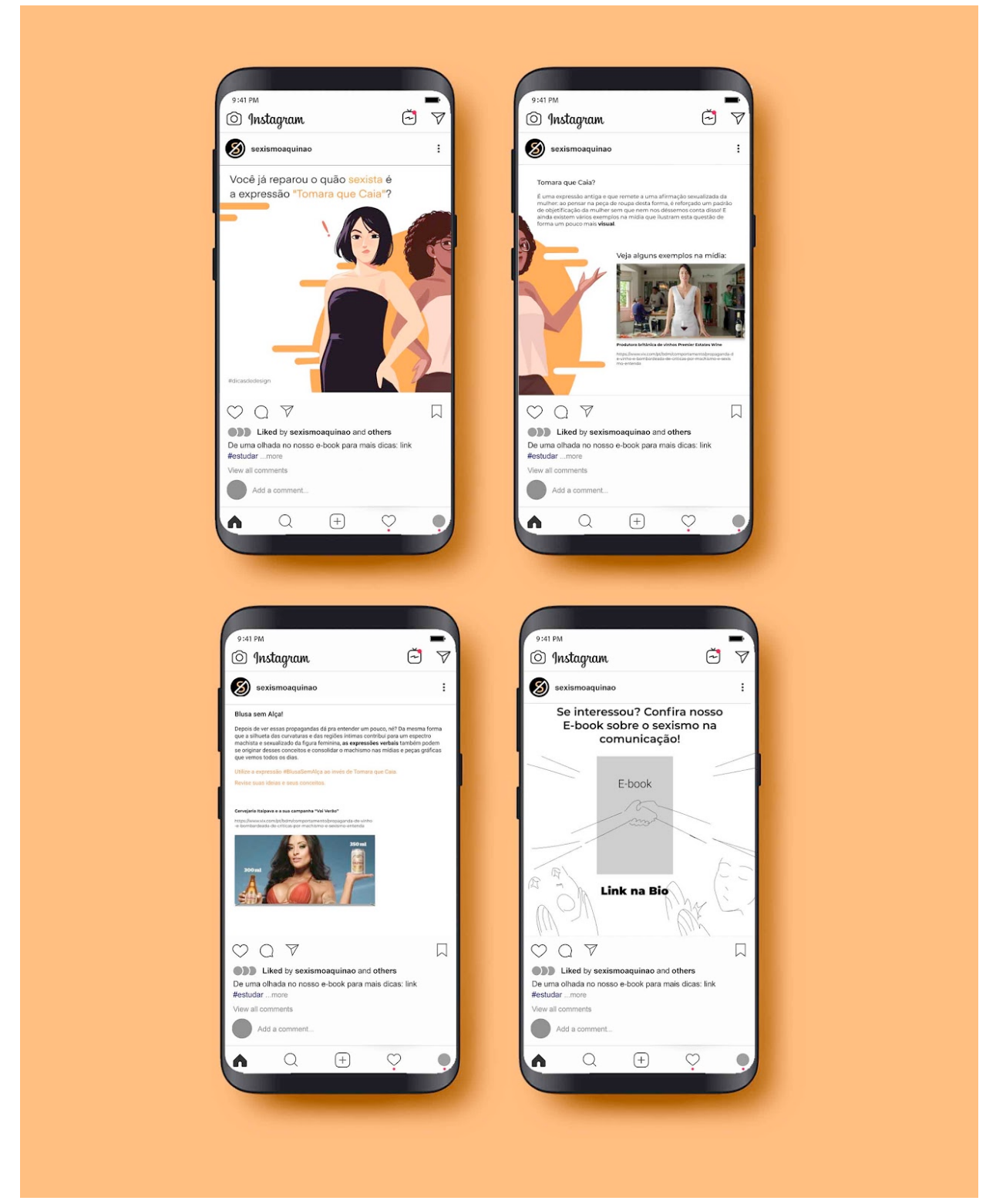

\section{Segundo Carrossel de Posts}

O segundo carrossel de posts (Figura 6) segue a mesma lógica do primeiro em termos de identidade visual, diagramação, frases em laranja e chamada titular no primeiro post. Os posts seguintes se enquadram na definição de design instrucional ao sugerir alternativas para evitar as representações colocadas como exemplo. Ao final do carrossel, há uma chamada exclusiva para gerar engajamento e, novamente, um direcionamento do leitor para o e-book. Dessa forma, a divulgação no Instagram permite despertar um interesse inicial do leitor apresentando conteúdos que serão apresentados no e-book de forma mais detalhada. 
Figura 6: Segundo carrossel de posts para Instagram e Facebook. Fonte: autoria própria.

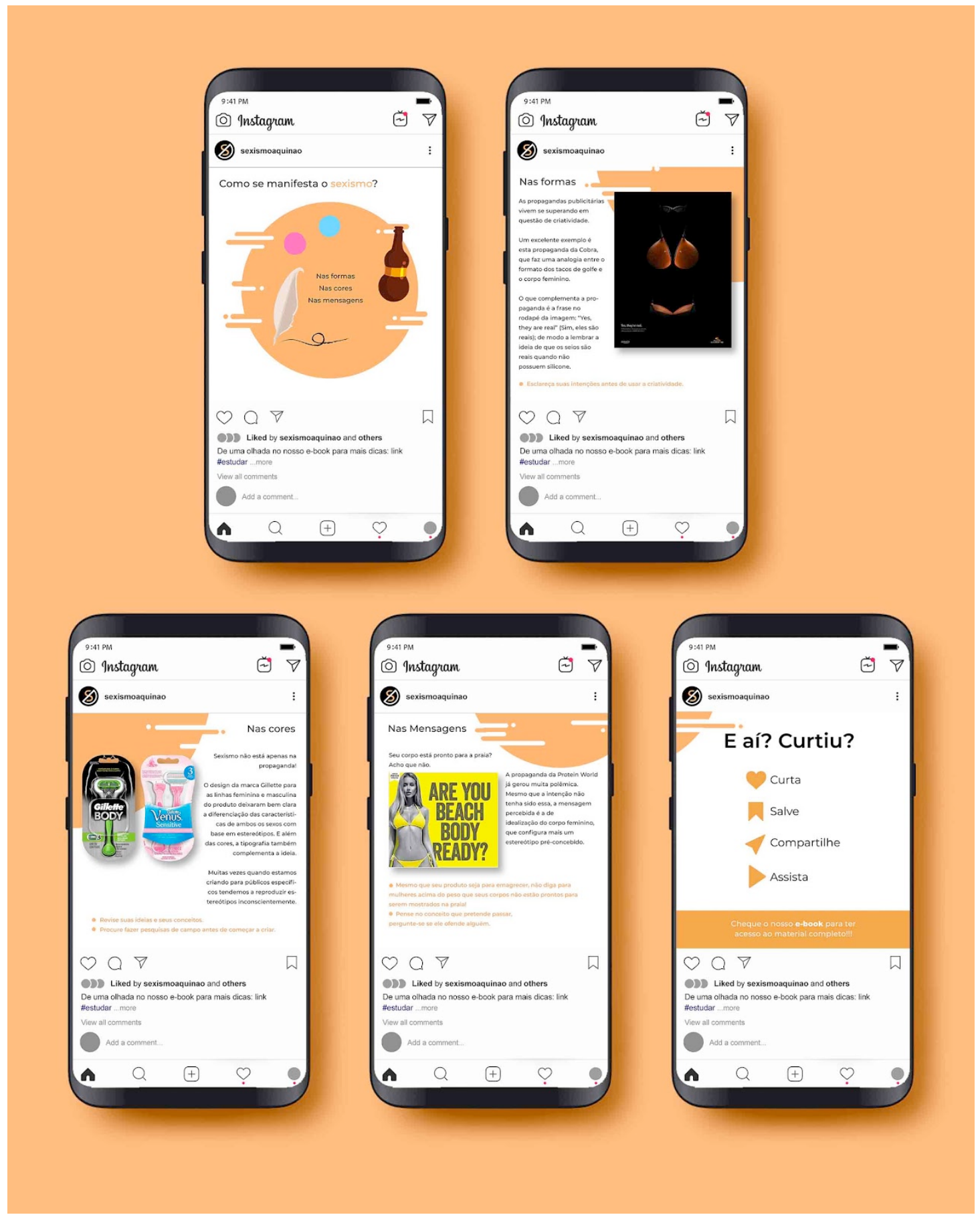

\section{E-book}

Pensado para ser disponibilizado via link da Bio no Instagram e descrição da conta do Facebook, o e-book (Figuras 7 e 8) foi desenvolvido a partir de conceitos pertinentes ao design instrucional, como o uso de elementos visuais (ilustrações) e dados textuais que orientam o usuário de modo direto, simples e rápido. As cores se apresentam em tons pastéis, em conformidade com uma linguagem simples e acessível. O objetivo do livro virtual é, além de informar sobre o panorama sexista das mídias, fornecer diretrizes para profissionais 
comunicativos que buscam amenizar a linguagem estereotipada em suas produções. Assim, os primeiros tópicos retratarão uma pequena introdução e modo de uso - com informações sobre a quem se destina o livro e o que será abordado -, além de explicitar alguns mecanismos de contornar os padrões, clichês e conteúdos discriminatórios envoltos nos fundamentos do design.

Figura 7: Exemplo de mockup do e-book em versão digital. Fonte: elaborado pelos autores.

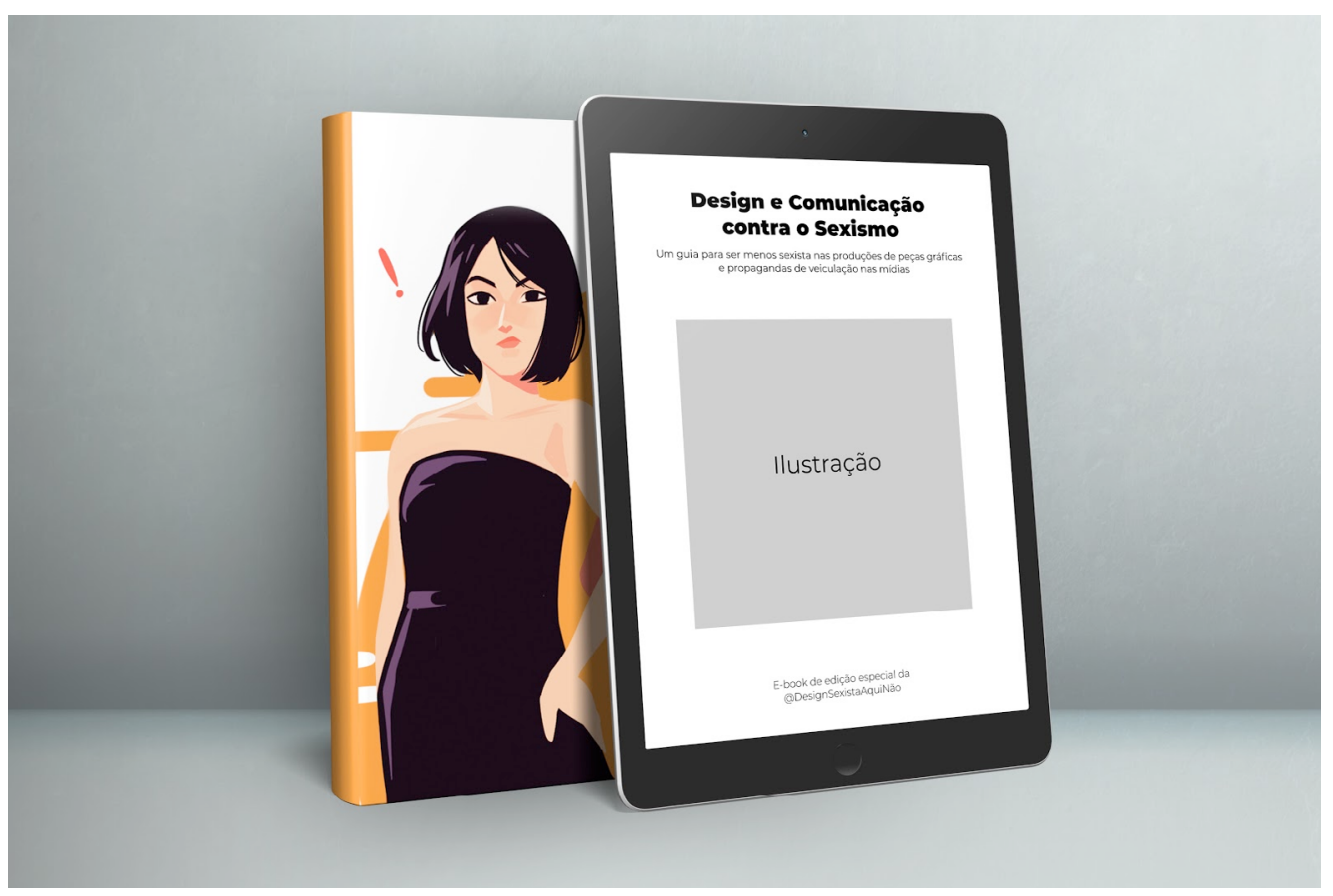

Figura 8: Esboços do E-book. Fonte: elaborado pelos autores.

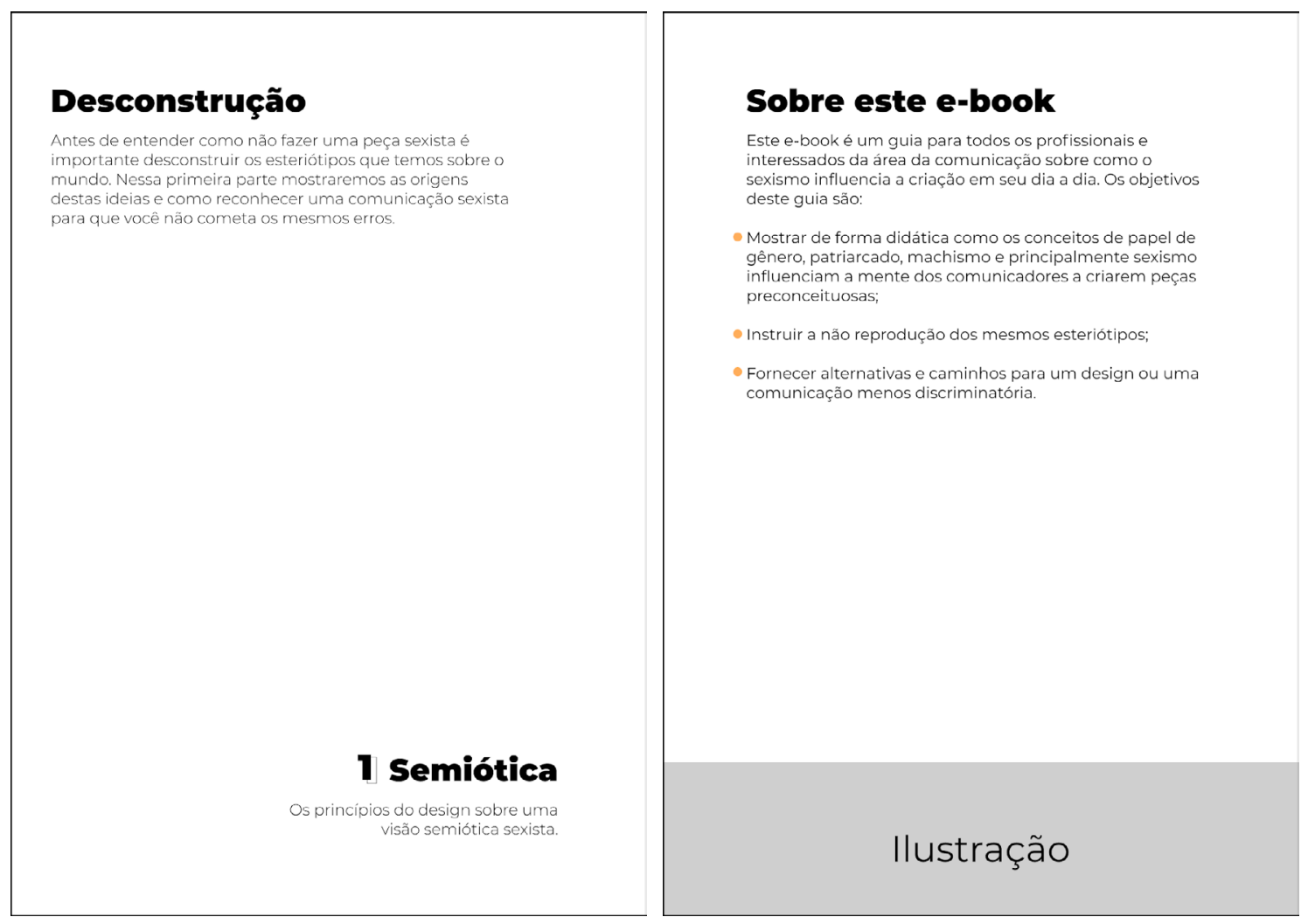




\section{Considerações Finais}

Diante do cenário sexista presente e consolidado nas mídias e na veiculação de propagandas desde as suas origens, entende-se que o problema abordado é complexo e exige não apenas a mobilização dos profissionais responsáveis por sua produção, mas também demanda a atenção da sociedade como um todo. Entretanto, entende-se que é possível fazer a diferença e iniciar um processo combativo a partir da tomada de responsabilidade e conscientização por parte dos comunicadores, que devem refletir sobre as suas produções e buscar por alternativas contra a discriminação e o estereótipo.

Desse modo, as ações projetuais abordadas envolvem o uso das mídias digitais, reconhecidas por sua acessibilidade e facilidade no compartilhamento rápido de informações e, principalmente, conhecimento. Assim, os resultados gerados pelo projeto realizado, junto ao embasamento do design instrucional, indicam a reflexão acerca da capacidade de gerar um engajamento e uma conscientização orgânicos, contínuos e escaláveis, alcançando indivíduos de diferentes classes sociais, etnias e idades todos os dias. Como a criação da conta do Instagram e a finalização do e-book não estavam dentro do escopo do presente artigo - já que foram produzidas peças-chave em formato de esboço a serem estudadas e analisadas junto ao público-alvo antes de sua implementação -, os próximos passos revelam a geração de conteúdo dentro de um perfil oficial e com a execução de um ciclo de avaliações e feedbacks recolhidos por meio de comentários na rede social, questionários e entrevistas com usuários. 0 método de Filatro e Piconez (2004) se encerra na fase de Avaliação, com a coleta de dados e testes, o que pode gerar um novo artigo com novos resultados por vir.

\section{Referências}

Almeida, F. S. \& Sousa, R. P. L. (2013). Aspectos do Perfil Profissional do Designer Gráfico Brasileiro. Educação Gráfica, v. 17, n. 1.

Belo, R. P, Gouveia V. V., Raymundo J. S., Marques C. M. C. (2005). Correlatos valorativos do sexismo ambivalente. Psicologia: reflexão e crítica, v.18, n.1, jan - abril.

Calegari C. M. K., Lima C. T., Civiriano J. (2013). Bauhaus: Histórico e influências nos dias de hoje. Revista Thêma et Scientia Edição Especial de Arquitetura e Design, v. 2, n. 2, jul/dez.

Carvalho R. L. V. R. (2012). Harold Lasswell e o campo da comunicação. (Doutorado em Comunicação). Universidade de Brasília, Brasília.

Ferreira, M. C. (2004). Sexismo hostil e benevolente: inter-relações e diferenças de gênero. XXX Reunião Anual da Sociedade Brasileira de Psicologia. Disponível em http://pepsic.bvsalud.org/scielo.php?script=sci_arttext\&pid=S1413-389X2004000200004. Acesso em set, 2020.

Filatro, A., Piconez, S. C. B. (2004). Design Instrucional Contextualizado. São Paulo: Senac.

Filho, M. M, Eufrásio C., Batista M. A. (2011). Estereótipos de Gênero e Sexismo Ambivalente em Adolescentes Masculinos de 12 a 16 Anos. Revista Saúde e Sociedade, v.20, n.3, p.554-567. 
Formiga, N. S. (2007). Valores humanos e sexismo ambivalente. Rev. Dep. Psicol.,UFF, v.19 n.2 Niterói July/Dec. 2007. Disponível em

https://www.scielo.br/scielo.php?pid=S0104-80232007000200009\&script=sci_arttext. Acesso em set, 2020.

Löbach, B. (2011). Design Industrial. Bases para a configuração dos produtos industriais. São Paulo: Blucher.

Montini, F. C.; Hoffman, R. (2016). O Design a Favor da Igualdade Social - Uma Análise sobre a Propaganda Sexista. Educação Gráfica, v. 20, n. 3.

Nucci, M. F. (2010). Hormônios pré-natais e a ideia do sexo cerebral: uma análise das pesquisas biomédicas sobre gênero e sexualidade. 104 f. Dissertação (Mestrado), Universidade Estadual do Rio de Janeiro, Programa de Pós-Graduação em Saúde Coletiva. Disponível em

http://www.bdtd.uerj.br/tde_arquivos/44/TDE-2010-09-02T083950Z878/Publico/NUCCI,\%20Marina.pdf. Acesso em set, 2020.

Oka, M., Laurenti, C. (2018) Entre sexo e gênero: um estudo bibliográfico-exploratório das ciências da saúde. Saúde e Sociedade, v. 27, p. 238-251. Disponível em https://www.scielosp.org/pdf/sausoc/2018.v27n1/238-251/pt. Acesso em set, 2020.

Paiva, F. (2020). 79,3\% dos brasileiros têm celular, informa IBGE. Disponível em: https://teletime.com.br/29/04/2020/793-dos-brasileiros-tem-celular-informa-ibge/. Acesso em out, 2020.

Rati, B. M., Beccari N. B. (2020). Estereótipos de gênero e apelos retóricos no design gráfico: um modelo de análise. Estudos em Design, v. 28, n. 1, pp. 06 - 26.

Rodrigues, T. M. M., Portinari D. B. (2016). Gênero no Design: a reprodução dos ideais de masculinidade e feminilidade. $P \& D$ Design, n. 2, v. 9, outubro, Belo Horizonte.

Royo, J. (2008). Design Digital. $1^{a}$ edição. São Paulo: Editora Rosari.

Socialbakers. (2019). Trends Report | Relatório de tendências de mídia social da Socialbakers. Disponível em:

<https://www.socialbakers.com/website/storage/2020/02/Q4TrendsReport_PortugueseVersi on.pdf>. Acesso em nov, 2020.

Sousa de J. K. L. L., Varão R. (2006). Harold Lasswell: as contribuições do "paladino" do saber comunicacional. NP 01 - Teorias da Comunicação: VI Encontro dos Núcleos de Pesquisa da Intercom.

The Guardian. (2020). KFC apologises for 'sexist' ad that shows young boys staring at woman's breasts. Disponível em https://www.theguardian.com/world/2020/jan/21/kfc-apologises-for-sexist-ad-that-showsyoung-boys-staring-at-womans-breasts. Acesso em jul, 2021.

We Are Social. (2020). Digital in 2020. Disponível em https://wearesocial.com/digital-2020. Acesso em nov, 2020. 


\section{Sobre os autores}

Victor Kraide Corte Real, Doutor, PUC-Campinas, Brasil victor.real@puc-campinas.edu.br Ana Júlia Broglio, Graduanda, PUC-Campinas, Brasil juzinhabrollo@gmail.com

Lívia Barbosa Gurgel, Graduanda, PUC-Campinas, Brasil livia_gurgell@hotmail.com

Mariana Magalhães Camacho Echeverre, Graduanda, PUC-Campinas, Brasil

mah.ny2@hotmail.com

Nycolas Pedro Martins Lima, Graduando, PUC-Campinas, Brasil nycolaspedro@gmail.com

Vitória Xavier Bailoni, Graduanda, PUC-Campinas, Brasil Vitoriaxb@yahoo.com 